\begin{tabular}{|l|l|}
\hline \multicolumn{2}{|c|}{ Toppan Best-set Premedia Limited } \\
\hline Journal Code: RADM & Proofreader: Mony \\
\hline Article No: RADM671 & Delivery date: 4 Jannary 2011 \\
\hline Page Extent: 10 & \\
\hline
\end{tabular}

\title{
Reshaping European metrology research - the role of national research managers
}

\section{Katharine E. Barker ${ }^{1}$, Deborah $\operatorname{Cox}^{2}$ and Thordis Sveinsdottir ${ }^{3}$}

\author{
${ }^{1}$ Manchester Institute of Innovation Research, Manchester Business School, The University of \\ Manchester, Manchester M13 9PL, UK. •• \\ 2Manchester Institute of Innovation Research, Manchester Business School, The University of \\ Manchester, Manchester M13 9PL, UK. deborah.cox@manchester.ac.uk \\ ${ }^{3}$ Manchester Institute of Innovation Research, Manchester Business School, The University of \\ Manchester, Manchester M13 9PL, UK. ••
}

\begin{abstract}
This paper deals with the role of research and development (R\&D) managers in shaping the landscape of public research in Europe. These R\&D managers work in the sphere of public research within national government laboratory services. The case we present is of the reconfiguration of metrology research. Metrology is the science of measurement. We examine why scientists and research managers in nationally embedded institutes, which are performing R\&D in support of national policy and local industry needs, have chosen to co-operate in a shared research programme. This means giving up, in part, their national sovereignty over funds and decision making. Furthermore, we examine how they have achieved the shared programme, which was launched as a European Commission (EC) programme through the Article $185^{1}$ initiative, which allows the $\mathrm{E}$ uropean $\mathrm{U}$ nion to participate in research programmes undertaken jointly by several Member States.
\end{abstract}

\section{Introduction}

$\mathrm{T}$ here has been an increase in international research collaboration, and this appears to be

3 continuing, facilitated by the developments in information and communications technology and by the existence of international funding programmes. This is prevalent in basic research. The landscape of research and development (R\&D) in Europe has been changing rapidly over the past decade. In 2000, the vision of the European Research Area (ERA) was introduced by the European Commission (EC). The main features of the ERA are 'mobility, the bundling of excellence across Europe, the upgrading of co-operation from specific, targeted research projects to larger networks, longer-term institutionalised co-operation and self-management by the European actors' (Edler, 2003). Furthermore, the long-term view is that national R\&D policies should become better coordinated and work more seamlessly together within the European Union (EU). A number of external developments have triggered this process, including the urgency of global grand challenges, the emergence of the BRIC countries ${ }^{2}$ and their entry into R\&D that meets high-quality standards, and the globalisation of R\&D. The issue of what position Europe should play in this process is increasingly important and is reflected in the aforementioned ERA ideology (European Commission, 2009). 
The EC has been fostering transnational coordination of public R\&D funding in support of developing the ERA. Partly, this is to reduce inefficiencies, duplication and the problems of smallness of scale. In addition, jointly programmed public research, to complement the Framework Programme instruments, can better address societal challenges. The Sixth Framework Programme introduced several new types of instruments to promote R\&D funding agencies and institutes in developing joint funding and priority setting in research (Horvat et al., 2006; Euro4 pean Union, 2011).

ERA-NET and Article 185 (renamed from Article 169) of the European Union Treaty were both seen as the most suitable schemes to start the process towards increasing co-operation and integration of national R\&D funding efforts. ERA-NET provides a bottom-up approach; it is open to all areas of research and the initiative, therefore, lies with the Member States to explore the possibilities of, and subsequently, set up joint research programmes. Article 185 of the European Union Treaty allows participation of the EU, as an equal partner, in new R\&D programmes undertaken jointly by several Member States. The main objective of Article 185 is to go beyond the mere coordination of national programmes and to achieve integration of different national and regional programmes in a single joint one. Since 2004, 'ERANET has proved an extremely effective way of stimulating the pooling of national programmes, with $96.2 \%$ of organisations in selected proposals being governmental, international or non-profit making bodies.' (European Commission, 2008b)

The introduction of the ERA, and the subsequent formation of ERA-NETS, required not only extensive mobilising of R\&D areas from the bottom up, but also upward political steering to achieve national level buy-in to the European R\&D co-operation. The internationalisation and Europeanisation of $R \& D$ have been widely documented and are often presented as a beneficial end in itself. What has received little attention is the question of the role that $R \& D$ managers could take in this process. This paper explores the case of the shared and competitive programme, the European Metrology Research Programme (EMRP), across Europe to meet both national and European strategic needs for the future. We consider whether R\&D managers in other fields with nationally based, public research institutes can or should take part in reshaping their research landscape through similar means.

Findings from a recent study of the metrology sector in Europe demonstrate that the example of the EMRP is a most revealing case. It shows how research managers have formulated and orchestrated a new funding model, namely a European programme of metrology research, which is now implemented as an Article 185 action. National metrology institutes (NMI) are highly diverse organisations in terms of size, funding, research capacity and national context, and now coordinate and share a common $\mathrm{R} \& \mathrm{D}$ programme. In contrast to basic research, metrology research supports specific national needs in relation to legislation and local industry. Thus, it is not obvious that there is a rationale for moving towards a shared programme. Yet, the EMRP is praised as an example of the successful implementation of a joint $R \& D$ programme through Article 185.

The paper will first outline our methods and approach to building the case study of public metrology institutes in Europe. For the purposes of building context, the history and field of metrology collaboration is outlined in some detail. In order to realise the impact of Europeanisation on the field of metrology, we describe the European research framework and its development for the past decade. We explore the motivations of NMI managers and their role in the integration efforts. From this case, we consider lessons for managers in other research fields that are currently exploring further European co-operation.

\section{Our methods and approach}

In 2009-2010, we studied the past and potential futures of research institutes in Europe (Arnold et al., 2010). The overall aim was to provide a basis for informing EU and national-level policies about the role of research institutes in the development of the ERA. The research covered secondary document analysis including websites, interviews with institute senior managers, and data collection for building indicators and for underpinning foresight techniques (scenario workshops). The data followed the indicator set developed in a previous study of European public research institutes (Georghiou et al., 2003). The aim, in addition to giving a thorough overview of the field in question, was to identify suitable institutions for further study.

We selected 11 metrology institutes that collectively provided a spread of geography, size and experience. We interviewed managers of these institutes and asked them about their current situation, the main recent changes affecting the organisation and changes to the environment for metrology research. Table 1 lists the metrology institutes included in the study and the reason why they were selected.

Based on the interviews and data collected, an account of the European metrology sector was 
Table 1. Selected national metrology institutes

\begin{tabular}{|c|c|c|c|}
\hline Institute & Acronym & Country & Reason for selection \\
\hline Bulgarian Institute of Metrology & BIM & Bulgaria & $\begin{array}{l}\text { Significant restructuring in the last decade } \\
\text { to harmonise with the EU }\end{array}$ \\
\hline Czech Metrology Institute & CMI & Czech Republic & $\begin{array}{l}\text { Disintegration of the Czech-Slovak } \\
\text { Federation resulted in the move of the } \\
\text { laboratory from government ownership } \\
\text { to independent organisation }\end{array}$ \\
\hline Danish National Metrology Institute & DFM & Denmark & Recently privatised and decentralised \\
\hline Laboratoire National d'Essais & LNE & France & $\begin{array}{l}\text { Large organisation, significant } \\
\text { restructuring, R\&D activities }\end{array}$ \\
\hline Physikalisch Technische Bundesanstalt & РTB & Germany & Large organisation, $R \& D$ activities \\
\hline Istituto Nazionale di Ricerca Metrologica & INRIM & Italy & Significant restructuring, $R \& D$ activities \\
\hline National Metrology Laboratory & NML & Ireland & Significant restructuring, negligible $R \& D$ \\
\hline Holland Metrology Group & HM & The Netherlands & Significant restructuring, $R \& D$ activities \\
\hline Central Office of Measures & GUM & Poland & R\&D activities \\
\hline $\begin{array}{l}\text { SP Technical Research Institute of } \\
\text { Sweden }\end{array}$ & SP & Sweden & Large organisation, $R \& D$ activities \\
\hline National Physical Laboratory & NPL & United Kingdom & $\begin{array}{l}\text { Significant restructuring, large } \\
\text { organisation, R\&D activities }\end{array}$ \\
\hline
\end{tabular}

written. Its aim was to identify change drivers and to describe patterns of change in the past 20 years or so, as a basis for subsequently running scenario workshops for experts within the selected institutes. Based on these accounts, we elaborated three scenarios: one positive, one negative and one involving disruptive transformation for the future development of the public research institute sector as a whole. We used the materials we had gathered to work out what these were likely to mean for the field of European metrology research. The workshop format brought together the senior managers and directors of national public metrology research institutes who had previously taken part in the interviews. In short, the group identified the implementation of Article 185 joint European programme as a major, recent transformation and spoke about their changing roles with respect to other national research institutes. They also concluded that an 'ideal' future scenario would involve an even greater Europeanisation of funding and organising metrology research (Barker et al., 2010).

\section{About metrology}

The mission of the metrology sector can be summarised as the development, maintenance and dissemination of measurement standards, and the development of metrology in new areas. Metrology institutes in European countries all participate in the process of metrology policy formulation. Metrology research is based upon expertise in various scientific fields traditionally dominated by physics. It is used to underpin economic activity across productive sectors, and is used by governments for regulation and standardisation essential for trade and functioning of goods and services. It is necessary for underpinning international standards and laws, and for supporting national compliance, for example with European Directives. As technologies become more advanced and cross-cutting, and novel technologies emerge, new research and expertise is needed for standards and measurement systems. Examples here are the pervasive exploration of nanotechnology applications and the need for sophisticated environmental monitoring.

\section{Mapping the sector}

Metrology research is organised in Europe NMIs, which conduct their research and provide their services on the basis of institutional funding from central government agencies or ministries. The organisation of the NMI varies as many of the NMIs are fully nationally owned, some are semi-public and a range of smaller institutes are in fact private but dependent upon national public funding. The NMIs vary in the tasks they perform, some providing reference services, some providing the primary standards, some delivering commercial services, some being researchintensive and others much less so. The metrology 
laboratory models operating throughout Europe are country-dependent, and are highly diverse in terms of structure, ownership, funding models and operation. In many countries, the metrology structure is highly centralised, while in others, it is decentralised, for example France. A result of this institutional arrangement is that metrology institutions house specialists, which are not typically found in universities or private sector research. The areas of expertise reflect the industrial and public sector measurement needs. In recent years, the metrology infrastructure in Europe, throughout the Member States, has been subject to some restructuring and change.

Some Member States, such as Denmark, have recently 'privatised' their metrology services. Since 2009, Danish Fundamental Metrology (DFM), a private company owned by the Technical University of Denmark, has coordinated metrology research in Denmark, helping companies and authorities with technological and measurement problems. DFM performs research in specific areas of fundamental metrology that are of special importance to the Danish situation. In 1995, in the United Kingdom, the National Physical Laboratory, once both UK government-owned and operated, became a government-owned company-operated organisation, essentially privatising the operation of the laboratory. However, no matter how 'private' the new services are, the newly reorganised services are still mandated to enterprises fully- or partially-owned by the national governments.

There has also been the creation and development of new institutes, for example in the Czech Republic in 1993 with the foundation of the Czech Metrology Institute, following the dissolution of the Czechoslovakian Federation. The overall landscape, however, in terms of number of institutes and relative sizes and research, has not changed dramatically as there is still a strong rationale for having a national institute in each country to provide specific support for industry, however small the country.

It is estimated that today Member States spend $€ 120$ million annually on metrology research [Com7 mission of the European Communities (CEC), 2008]. Most investment in metrology is spent via the NMI and associated Member State 'Designated Institutes' in Europe, with less than $10 \%$ subcontracted outside these institutes. Funding of metrology research is highly skewed across the EU 27. The 'big four' metrology laboratories are to be found in Germany, the United Kingdom, France and Italy. It should also be noted that the EC has a Joint Research Centre devoted to metrology, located in Belgium, the Institute for Reference Materials and Metrology (IRMM). ${ }^{3}$
Within minor exceptions (such as the Czech Metrology Institute which was created after the split with Slovakia), budgets for metrology services and metrology research have been level and not increasing much or likely to increase greatly. This produces what other authors describe as the 'metrology dilemma'. This argument states that metrology faces increasing demands from a broad range of industries, including new industrial applications and government needs for regulation, public health and policy, representing societal needs. (CEC, 2008) The demands are not only growing more diverse but also more complex in terms of the science and technology, and this points to collaboration across fields and development of metrology outside the traditional physics-based areas. Metrology is stretched, yet collaboration could help solve the problem through developing a common strategy and utilising European specialisms. Moreover, there remains a great deal of duplication of metrology services and metrology research, but it seems that some duplication is needed for key areas and in order to deliver services to local industry. It is less clear that there is a need for significant duplication of research, as opposed to service delivery.

This diversity in terms of the landscape of NMIs is one of the puzzles as to why such varied institutes and programmes would want to lock in together in a programme of research. From an institutional point of view, this does look perplexing; however, the environment for funding and the broadening needs for metrology research to diversify to support new industries with different technological bases and increasing environmental regulation is a stronger force, which has pushed the NMIs to co-operate in order to achieve their missions.

\section{Progressive European co-operation}

The common denominator for the metrology sector is that all the NMIs are members of European and international metrology networks, in particular the European Association of National Metrology Institutes (EURAMET) $^{4}$ and the European Cooperation in Legal Metrology WELMEC. ${ }^{5}$ WELMEC's aim is to establish a harmonised and consistent approach to European legal metrology. EURAMET is a regional metrology organisation in Europe. It coordinates the co-operation of NMIs in Europe in research, traceability of measurements to the SI units, international recognition of national measurement standards, and the calibration and measurement capabilities of its members. 
This particular institutional structure of service delivery and calibration for the metrology sector, therefore, means that European collaboration was already firmly in place with formal networks of metrology experts representing their national institutes. This was undoubtedly the key in allowing the development of collaborative research programmes.

The EUROMET co-operation structure (forerunner to EURAMET) formed the basis for a series of collaborative metrology projects, which utilised the ERA-NET instruments. ERA-NETS were launched within the European Communities Sixth Framework Programme for research and development (20022006). The objective was to encourage and subsidise networking and coordination of funding agencies within different European countries, rather than the usual co-operative R\&D projects. The NMIs first used a support project, Metrology in the European Research Area (MERA), to work together in scoping the needs for metrology services and to provide evidence to justify increasing co-operation in research. Two successive ERA-NETS were also able to include funding agencies.

The European metrology laboratories then used this opportunity to work towards implementation of joint research calls in specific areas. Early on, they had identified the need to explore the Article 169 (now renamed 185) instrument. Generating evidence through industry surveys, foresight exercises and economic studies, the R\&D managers gradually built up their case. They are now working with parent ministries. This collaboration (iMERA) led to the reformation of EUROMET into EURAMET so that it could legally operate and manage joint research programmes.

The EMRP was born, implemented first through the IMERA Plus, in the Seventh Framework Programme and then through Article 185, and both phases attracting additional investment (co-funding) from the EC. The first phase of the EMRP has more than $€ 64 \mathrm{M}$ committed to R\&D, which includes an input of $€ 21 \mathrm{M}$ from the EC.

The number of countries taking part in European metrology research collaboration has increased from 11 in the Fifth Framework Programme to 22 committing to the Article 185 of the EC Treaty, which was approved by co-decision in July 2009. The Commission Staff Working Document (CEC, 2008) states that the annual estimated portion of national funding that could be freed up from national control to be 'European' is about $€ 200 \mathrm{M}$ over 6-7 years. The EMRP attracts co-funding from the Commission, and so this would effectively double the budget for 'European' metrology research by matching the 9 fund created by the member countries. This would put the balance of national and European metrology research to $56 \%: 44 \%$, were a $€ 200 \mathrm{M}$ fund from the Commission to be available over the next 6-7 years. This situation has not happened overnight, it has taken dedicated coordination from R\&D metrology sector managers to prepare evidence, work out the details of implementation and mobilise the political level.

\section{Motivations for metrology managers}

During the course of the interviews and in the workshops in our study, the metrology experts identified drivers that are affecting the metrology sector. Metrology institutes are increasingly linked to the academic system, providing access needed to additional disciplines, sometimes at the cost of an increasingly academic set of incentives being employed in an applied context. Metrology sector managers report that national funding is reduced and seems not likely to grow to meet changing needs, which means that European funding is of great importance.

In the metrology sector, we are seeing simultaneous needs to increase the amount of applied research done and to move into measurement in new fields, such as biotechnology and nanotechnology. Traditional areas of industry are becoming more complex, and require broader measurement ranges and lower uncertainties. Our understanding of key issues, including climate change, food safety and air quality, all rely on our ability to make ever better measurements and make new demands of metrology (Henson et al., 2009). This involves creating new capabilities, offering the chance to optimise their location at the European rather than the national level, and to build globally competitive critical mass. Duplication of research and capabilities in the past means that there is a clear case for rationalisation, an agenda that has, for some time, been pursued within the European co-operation, although more in making decisions about locating new capabilities than in deciding which existing capabilities can be eliminated. The growth of the emerging economies means that Europe's past quasi-monopoly of metrology has disappeared, leaving a need for European metrology research to tackle global competition. Global competition stems mostly from the United States, the Asia Pacific Metrology programme and a recent Metrology programme from Russia.

These arguments are all made at a national and European policy level. At research institute level, there can be potential losses, such as closing down of areas of $\mathrm{R} \& \mathrm{D}$ and failure to win $\mathrm{R} \& \mathrm{D}$ funding, which is now competitive and allocated through the 
EMRP. Here, the rationale for $R \& D$ managers to push European co-operation may not be obvious. However, some of the smaller metrology institutes, such as the Instituto Português da Qualidade, have still taken part in the EMRP. Clearly most of the national managers were motivated by the potential benefits from changing to a European co-operative mode: the chance to grow and develop metrology $\mathrm{R} \& \mathrm{D}$, gain more funding and compete more effectively at a global level.

\section{What is the role of managers in European integration?}

Managing the European integration of metrology research has been a complex undertaking and has taken extensive effort over a number of years, bringing together the views of more than 20 countries, their NMIs and ministries' (Henson et al., 2009). Critical success factors in this process have been a nuanced understanding of key issues and the landscape within which NMIs operate, a careful assessment of the said case and the likelihood of motivating different institutions to work towards a common vision. The EMRP has reached a very high level of integration and has been successful in creating a central management and project selection process, which has been fully honoured by all participating countries. This success, in part, has been attributed to the funding model, whereby participating countries earmark and put forward a designated amount to the overall budget of the EMRP. The Member States also pledge to have spare funds should they be successful in their bidding. This is seen to encourage integration and commitment of the participating states, and furthermore ensures that projects are never held back due to lack of funds.

In the case of metrology, most institutions had experience of co-operation and were working within the framework of internationally applicable measurements. Careful consultation with external stakeholders was carried out throughout the process of the MERA and iMERA projects in order to keep tabs on expectations and needs of the wider community. Starting small, with only a few members, also proved to be successful as a good track record could be more easily achieved, which in turn convinced new members to join the MERA, iMERA, and later, EMRP programmes.

Awareness of different stakeholders and audiences while developing co-operation in R\&D is imperative. Explaining the value of metrology and the programme to MEPs who likely had little awareness of its benefits was carried out over the course of 2 years and included invitations to MEPS to visit NMIs in each country. This proved to be very important when it came to convincing NMIs to take up the full Article 185 (Henson and Wittke, 2009).

The EMRP has provided NMIs with both a coordination mechanism and a competitive arena in which specialist capabilities can develop scale and excellence. Reaping the benefits of this specialisation will pose a new challenge: 'distribution' of new metrology services. Over time, this - together with the clear opportunities for rationalisation in the field - may lead to a specialisation among institutes; some largely with 'retail' knowledge, while others undertake a mixture of production and retailing. Without some such arrangement, it will be hard to offer a comprehensive set of measurement services across Europe.

Prior to the establishment of EMRP, EUROMET had organised collaboration projects in three fields: comparisons of measurement standards, traceability, and consultations of facilities (Schwitz, 2003). While two of the types of project were very successful (comparisons of measurement standards and consultation of facilities), success was rather limited in metrology R\&D collaboration. Furthermore, most of the proposed projects originated from and were established within the individual EUROMET technical committees for each of the various metrology disciplines (Erard et al., 2006), and were thus one dimensional in nature. What also complicated collaboration efforts during EUROMET was the fact that the NMIs were previously not able to formally commit their laboratory resources, or to influence the timing of available national resources to achieve the alignment necessary for success.

According to Edler et al. (2008) there was an urgent need to further open up the NMI community across Europe, both between NMIs and also between the academic community in general and the NMIs, to stimulate cross-fertilisation and allow the NMIs to break out of their traditional specialisation fields.

What the EMRP offered was a new possibility to allow for the planning and funding of very large scale, fully coordinated metrology research projects that are built around grand challenge themes, which was one of the rationales of the ERA. (European Commission, 2008a) These had previously been beyond the resources of any single NMI. Pulling NMIs into a competition for funds, and to do so at the European rather than the national level, opened up competition where none was before. This allowed for enhanced excellence and efficiency. (European Commission, 2008a, p. 15)

The key role of research managers in the European research arena has been and remains to build up and support coalitions for collaboration in research. 
Managers have successfully responded to greater demands from industry for increased precision and wider scope, as well as new demands from biotechnology and nanotechnology. While realising that individual NMI budgets would not stretch to meet these demands, the MERA and iMERA projects investigated and prepared how to pool national and EC funding in a joint EMRP.

The EMRP works from a 'virtual common pot' funding model that includes countries each paying for their own participants and contributing towards the programme management funds. Of the $€ 200 \mathrm{M}$ committed by the participating countries under Article 185 , there is $€ 20 \mathrm{M}$ that funds programme management costs and contributes towards the researcher grants. This type of common pot does not actually establish a joint budget to finance the selected individual projects but is based on national/regional contributions. The government of each Member State must earmark and pledge a specific amount to the EMRP pot. The NMIs decide on priorities (national or joint) and bid for funding to the virtual common pot. All project proposals bids are collaborative, as in each Joint Research Project Consortium (JRP) must contain a minimum of three organisations from at least three participating states. In practice, all of the JRPs include more participants and more countries than the minimum.

What this means for the managers of NMIs is that they need to clearly set out national priorities that involve collecting the needs of industrial stakeholders (European or national) as well as research labs before bidding, which encourages collaboration and integration throughout the metrology community. The role of managers has also been to realise the challenge that new technologies and advances in science bring, and make sure these are present in national priority setting.

\section{Lessons for other fields with nationally based public research institutes}

The field of metrology research has a long history of co-operation and membership organisations (first EUROMET, then EURAMET) that have represented European metrology and coordinated research and development efforts. NMIs have been willing to surrender national positions in some areas of metrology in order to create a more European knowledge base. Managers from the partner NMIs have a say in what priorities are set for European metrology each year, and this has proved to work well in creating a consensus within the field. Within fields that are less advanced in terms of European co-operation, the surrendering of some control would greatly assist the building of joint research programmes. For some fields, a starting point could be the sharing of data across Member States. It is to be expected that duplication of research and services will occur, and in some instances, this will be appropriate in order to deliver these successfully to local industries. Managers need also to bear in mind the rapid growth and high quality of many research fields in Asia, and how to respond to this new competition. European collaboration and funding through initiatives, such as Article 185, could be seen as a good option for establishing networks of national research institutes that could better compete in a global environment.

Interviews with NMI managers and representatives of EURAMET revealed that, in order to successfully take part in collaborative projects, most institutes had to establish a specialisation in order to increase their power of negotiations. Very few NMIs have the potential of covering the whole breadth of metrology services and R\&D, so each has worked hard to focus their work in order to find a specific niche. This allows for stronger negotiation potential when it comes to forming consortia and collaborator networks. This will take time if specialisation is not already established, and in the meantime, institutes should take care to be involved in other ways, for example by acting as conduits for linking up subcontract work for other NMIs and national industry.

Establishing a 'virtual common pot' method of funding, whereby Member States partly give up the sovereignty of funds, has proven to work well to harmonise European and national interests in metrology. Furthermore, the involvement of stakeholders early in the process of deciding national and European priorities has seemed to further amplify this process. The role of managers here would be to help establish national priorities and find ways of harmonising these with European priorities, for example by looking towards the solution of grand challenges (European Commission, 2008b).

Removal of incentives that lock institutes in working within a national market would also greatly help in making European research collaboration easier. This would be an opportunity for managers in the $R \& D$ sector to influence the policy agenda within each Member State, with the aim of building a more favourable landscape for European co-operation in research.

It is important to keep in mind that each field is a specific case, and there is not likely to be a one-size-fits-all approach to achieving a balance between co-operation and competition. Increasing co-operation may result in increasing specialisation 
Katharine E. Barker, Deborah Cox and Thordis Sveinsdottir

Table 2. Advantages and disadvantages of integration and independence for metrology research institutes

\begin{tabular}{|c|c|c|}
\hline & Advantages & Disadvantages \\
\hline \multirow[t]{4}{*}{ Independence } & Sovereignty of funds and decision making & $\begin{array}{l}\text { National research/equipment funding is likely to be } \\
\text { at least level in most fields }\end{array}$ \\
\hline & Can tailor R\&D to local industry needs & $\begin{array}{l}\text { Many institutes face an increase in the scope of } \\
\text { their work due to new technological advances and } \\
\text { transnational challenges }\end{array}$ \\
\hline & & Duplication of work \\
\hline & & $\begin{array}{l}\text { Increased need for more interdisciplinary } \\
\text { collaboration }\end{array}$ \\
\hline \multirow[t]{6}{*}{ Integration } & $\begin{array}{l}\text { Access to a dedicated metrology virtual pot } \\
\text { funding }\end{array}$ & $\begin{array}{l}\text { Smaller countries find themselves unable to bid on } \\
\text { as many projects as larger countries }\end{array}$ \\
\hline & Able to tackle transnational challenges & Prioritisation decided at a European level \\
\hline & Greater access to interdisciplinary teams & $\begin{array}{l}\text { Member States put the money upfront, but there is } \\
\text { no guarantee that their projects will be funded }\end{array}$ \\
\hline & $\begin{array}{l}\text { Better able to take on competition from BRIC } \\
\text { countries }\end{array}$ & $\begin{array}{l}\text { Members need to have a research element of their } \\
\text { metrology budget to be able to take part }\end{array}$ \\
\hline & Stakeholders are involved from the start & \multirow{2}{*}{$\begin{array}{l}\text { Need to reapply for European funding and Article } \\
185 \text { after each period, in increasingly competitive } \\
\text { funding environment }\end{array}$} \\
\hline & $\begin{array}{l}\text { Opportunity to develop strength through } \\
\text { specialisation }\end{array}$ & \\
\hline
\end{tabular}

BRIC, Brazil, Russia, India, and China.

and diversification, with centres of excellence emerging. This has been the case within metrology where NMIs have developed specific strengths, for example the National Physical Laboratory in the United Kingdom and the PTB in Germany are very focused on R\&D, while FMI in Finland and ESL in the Netherlands are focused on fundamental metrology.

Table 2 distils our analysis of the advantages and disadvantages of independent $R \& D$ programmes versus the integrated programme. There is evidence that other sectors are also beginning to organise along similar lines. Examples include the geosurveys sector which shows similarities to metrology research, in that it is nationally specific while being relevant to the solution of the European Grand Challenges with respect to environmental concerns. Work is ongoing within that sector with the establishment of EuroGeoSurveys, ${ }^{6}$ which aims to promote geosurveys to the EU, and increase collaboration and data harmonisation between the 32 geological surveys institutes that are members (Technopolis 11 Group, 2009).

\section{Conclusion}

This paper has reflected upon some of the lessons for research managers which the metrology case offers for other domains to create a co-operative programme of research in a pan-European frame- work. Based on the wider scope of our recent research, it is clear that public research institutes in other applied and policy support fields also identify the need for more European co-operation (Arnold et al., 2010). There are diverse drivers for this, including gain additional resources, stay in the game, avoid slow decline, gain a foothold in research, develop new strengths, gain prestige and start moves for European services. The metrology case demonstrates that perceived threats to national research programmes and the expected benefits from pooling have been sufficiently argued to launch the European programme.

The European Commissioner has set the broad policy framework for the integration of research under the ERA-Lisbon agenda. What the managers have done within that framework is written arguments to develop the research programmes. They have persuaded national policy makers and ministries, officials and EC policy makers that this warrants the input of resources. Using resources in the European networks, they have built up the evidence base to generate evidence of synergies, co-operations and convince Member States to commit to Article 185. The research managers have not just implemented research and research projects but have also designed and driven arguments for whole programmes of research and continuations of those programmes. This has been done at the level of national laboratory managers rather than national government ministries. R\&D managers in other sectors of 
national public research may consider similar actions in order to develop their own European research agenda and the access to funding which it can bring.

The evolution of metrology research and the extent to which the expected benefits will be realised remains to be seen. Further research needs to document whether, for example, new research direction and interdisciplinary teams emerge, and whether these capabilities allow European research to remain competitive with respect to global standards.

\section{Acknowledgements}

The authors would like to acknowledge the support of the European Commission, DG Research contract number 30-CE-0243755/00-51 and of Technopolis Plc, Brighton, UK, contract coordinator.

Equal credit in production of this article is afforded to the authors.

\section{References}

Arnold, E., Barker, K., and Slipersæter, S. (2010) Research institutes in the ERA. Available at http://ec.europa.eu/ research/era/docs/en/research-institutes-in-the-era.pdf

Barker, K., Cox, D., and Sveinsdottir, T. (2010) Foresight on the future of public research metrology in Europe. Foresight, 13, 1, 5-18.

Commission of the European Communities (CEC). (2008) Staff Working Document accompanying the decision of the European Parliament and the Council on the participation by the Community in a European Metrology Research Programme undertaken by several member states: impact assessment report. COM 2008 814, Brussels.

Edler, J. (2003) Change in European R\&D policy as a complex consensus building process: experiences from the past and what they can tell us about the future. In: Edler, J., Kuhlman, S., and Behrens, M. (eds), Changing Governance of Research and Technology Policy: The European Research Area. Cheltenham: Edward Elgar Publishing Ltd. pp. ••-•••

Erard, L., Magana, J.-F., Perissi, R., Reposeur, P. and Virieux, J.-M. (2006) Organisation of metrology: industrial, scientific, legal. In: The French College of Metrology (ed.), The Key for Quality, Metrology in Industry. ••: •• pp. ••••. ISBN-13:978-1-905209-51-4.

Euramet. (••) Background information on the EMRP. Available at http://www.emrponline.eu/edocs/emrp_ background.pdf

European Commission. (2008a) Challenging Europe's research: rationales for the European research area. Report of the ERA Expert Group. EUR 23326 EN.

European Commission. (2008b) ERA-NET, Networking in the European Research Area: Coordination of National 17 Programmes. ••: ••. ISBN 978927909522-1.
European Commission. (2009) Drivers of international collaboration in research: final report. EUR 24195 EN.

European Union. (2011) Innovation union competitiveness report 2011 edition. EUR 24211.

Georghiou, L., Cox, D., Keenan, M.P., Flanagan, K., and Barker, K.E. (2003) A comparative analysis of public, semi-public and recently privatised research centres, summary final report. Available at ftp://ftp.cordis. europa.eu/pub/indicators/docs/ind_report_prest1.pdf

Henson, A. and Wittke, W. (2009) Implementing the Metrology European Research Area iMERA: Publishable Final Activity Report. ••, UK: National Physical Laboratory.

Henson, A., Kühne, M., and Erard, L. (2009) The European metrology programme in action. Measure, 4, 4, 26-33.

Horvat, M., Guy, K., Demonte Barreto, V., Engelbrecht, J., and Wilken, K. (2006) ERA-NET review 2006. The Report of the Expert Review Group, December.

iMERA. (2008) European metrology research programme: outline 2008. Available at http://www.emrponline.eu/ edocs/emrp_outline_2008.pdf

Schwitz, W. (2003) -EUROMET - the collaboration of European national metrology institutes. Measurement, 33, 2, 189-195.

Technopolis Group. (2009) Analysis of Public Research Institutes: Six Cases. Technopolis Ltd, Brighton, UK (unpublished).

\section{Notes}

1. The Lisbon Treaty came into force on 1 December 2009. As a result, the numbers of the articles were amended, and Article 169 became Article 185.

2. The BRIC countries are Brazil, Russia, India and China.

3. IRMM is a member of EURAMET.

4. EURAMET was inaugurated on 11 January 2007 as the successor to EUROMET, hence this report refers to one organisation or the other depending upon the source document. For further information on EURAMET, see http://www.euramet.org

5. For further information on WELMEC, see http:// www.welmec.org/

6. For further information, see http://www. eurogeosurveys.org/

Katharine Barker is a Senior Lecturer at the Manchester Institute of Innovation Research, Manchester Business School, The University of Manchester, UK, where she coordinates the $\mathrm{PhD}$ programme. She teaches and leads the MSc Innovation Management and Entrepreneurship course, which attracts around 75 students from all around the world. Her research field is public sector science and evaluation, and she has recently worked on understanding the social impacts of research. She regularly trains policy makers and managers in research evaluation through 
short courses at the MIOIR and University of Twente. She has worked on topics surrounding change in public research, including public research institutes and more recently universities. She has published in Research Evaluation, Technology Analysis \& Strategic Management and Foresight.

Deborah Cox is a Research Fellow at the Manchester Institute of Innovation Research, Manchester Business School in The University of Manchester, UK. Her academic qualifications are in social sciences and information management. She has published, with colleagues, in Science and Public Policy, Foresight, Technology Analysis and Strategic Management, Accounting, Auditing \& Accountability Journal, and Journal of Documentation, and is a co-author on the monograph Scrutinizing Science,
The Changing UK Government of Science published by Palgrave MacMillan. Her current research is in the field of STI policy research, and has recently been concerned with public sector research systems and the socio-economic impacts of research.

Thordis Sveinsdottir is a Researcher at the Manchester Institute of Innovation Research, Manchester Business School, The University of Manchester, UK. She received her $\mathrm{PhD}$ in Sociology from the University of Surrey, UK. Her work has appeared in Foresight. Her current research focuses on science and innovation policy and innovation within the creative industries, especially in the field of online games. She teaches Research Methods to MSc students on the Innovation Management and Entrepreneurship course at the Manchester Business School. 


\section{AUTHOR QUERY FORM}

Dear Author,

During the preparation of your manuscript for publication, the questions listed below have arisen. Please attend to these matters and return this form with your proof.

Many thanks for your assistance.

\begin{tabular}{|c|c|c|}
\hline $\begin{array}{l}\text { Query } \\
\text { References }\end{array}$ & Query & Remarks \\
\hline 1 & $\begin{array}{l}\text { AUTHOR: A short title running head was not supplied. } \\
\text { Please check if this one is suitable and, if not, please supply } \\
\text { a short title that can be used as a running head. }\end{array}$ & \\
\hline 2 & $\begin{array}{l}\text { AUTHOR: Please provide the email addresses of the } \\
\text { authors Barker and Sveinsdottir. }\end{array}$ & \\
\hline 3 & $\begin{array}{l}\text { AUTHOR: Is information and communications technology } \\
\text { the correct full form of ICTs? Please change if incorrect. }\end{array}$ & \\
\hline 4 & $\begin{array}{l}\text { AUTHOR: European Commission } 2011 \text { has been changed } \\
\text { to European Union, } 2011 \text { so that this citation matches the } \\
\text { Reference List. Please confirm that this is correct. }\end{array}$ & \\
\hline 5 & $\begin{array}{l}\text { AUTHOR: Arnold et al. } 2011 \text { has been changed to Arnold } \\
\text { et al., } 2010 \text { so that this citation matches the Reference List. } \\
\text { Please confirm that this is correct. }\end{array}$ & \\
\hline 6 & $\begin{array}{l}\text { AUTHOR: Figures } 1 \text { and } 2 \text { (as shown in the manuscript } \\
\text { submitted) have been changed to Tables } 1 \& 2 \text {, respectively. } \\
\text { Please confirm that this is OK. }\end{array}$ & \\
\hline 7 & $\begin{array}{l}\text { AUTHOR: CEC, } 2008 \text { has been changed to Commission of } \\
\text { the European Communities, } 2008 \text { so that this citation } \\
\text { matches the Reference List. Please confirm that this is } \\
\text { correct. }\end{array}$ & \\
\hline 8 & AUTHOR: Please provide the full form of WELMEC. & \\
\hline 9 & $\begin{array}{l}\text { AUTHOR: "This would put the balance. .." The meaning } \\
\text { of this sentence is not clear. Please rewrite or confirm that } \\
\text { the sentence is correct. }\end{array}$ & \\
\hline 10 & $\begin{array}{l}\text { AUTHOR: Edler et al. } 2008 \text { has not been included in the } \\
\text { Reference List. Please supply full publication details. }\end{array}$ & \\
\hline 11 & $\begin{array}{l}\text { AUTHOR: Technopolis, } 2009 \text { has been changed to } \\
\text { Technopolis Group, } 2009 \text { so that this citation matches the } \\
\text { Reference List. Please confirm that this is correct. }\end{array}$ & \\
\hline 12 & $\begin{array}{l}\text { AUTHOR: Arnold et al. } 2009 \text { has been changed to Arnold } \\
\text { et al., } 2010 \text { so that this citation matches the Reference List. } \\
\text { Please confirm that this is correct. }\end{array}$ & \\
\hline 13 & $\begin{array}{l}\text { AUTHOR: Please check all website addresses and confirm } \\
\text { that they are correct. (Please note that it is the responsibility } \\
\text { of the authors to ensure that all URLs given in this article } \\
\text { are correct and useable.) }\end{array}$ & \\
\hline
\end{tabular}


JOBNAME: No Job Name PAGE: 12 SESS: 30 OUTPUT: Wed Jan 4 19:01:25 2012 SUM: 28670FBA

/v2451/blackwell/3G_journals/radm_v0_i0/radm_671

\begin{tabular}{|c|c|c|}
\hline $\begin{array}{l}\text { Query } \\
\text { References }\end{array}$ & Query & Remarks \\
\hline 14 & $\begin{array}{l}\text { AUTHOR: Please supply the page range of the article for } \\
\text { Edler } 2003 \text {. }\end{array}$ & \\
\hline 15 & $\begin{array}{l}\text { AUTHOR: Please supply the name of the publisher and its } \\
\text { location as well as the page range of the article for Erard } \\
\text { et al. } 2006 \text {. }\end{array}$ & \\
\hline 16 & $\begin{array}{l}\text { AUTHOR: Please supply year of publication for the } \\
\text { Euramet article. }\end{array}$ & \\
\hline 17 & $\begin{array}{l}\text { AUTHOR: Please supply the name of the publisher and its } \\
\text { location for European Commission 2008b. }\end{array}$ & \\
\hline 18 & $\begin{array}{l}\text { AUTHOR: Please supply city location of the publisher for } \\
\text { Henson and Wittke } 2009 \text {. }\end{array}$ & \\
\hline 19 & $\begin{array}{l}\text { AUTHOR: Please note that Henson and Wittke 2009a and } \\
\text { Henson et al. 2009b has been changed to Henson and } \\
\text { Wittke } 2009 \text { and Henson et al. 2009, respectively, to follow } \\
\text { journal style. Citations in text have also been modified } \\
\text { accordingly. Please check and confirm that the changes } \\
\text { made are correct. }\end{array}$ & \\
\hline 20 & $\begin{array}{l}\text { AUTHOR: Although iMERA has been mentioned in the } \\
\text { text a couple of times, no clear indication of iMERA, } 2008 \\
\text { was cited. Please indicate where this reference should be } \\
\text { cited. }\end{array}$ & \\
\hline
\end{tabular}




\section{Please correct and return this set}

Please use the proof correction marks shown below for all alterations and corrections. If you wish to return your proof by fax you should ensure that all amendments are written clearly in dark ink and are made well within the page margins.

\begin{tabular}{|c|c|c|}
\hline Instruction to printer & Textual mark & Marginal mark \\
\hline Leave unchanged & ... under matter to remain & ( ) \\
\hline $\begin{array}{l}\text { Insert in text the matter } \\
\text { indicated in the margin }\end{array}$ & $h$ & $\begin{array}{l}\text { New matter followed by } \\
h \text { or } h \otimes\end{array}$ \\
\hline Delete & $\begin{array}{l}\text { I through single character, rule or underline } \\
\text { or }\end{array}$ & $\sigma$ or $\sigma(x)$ \\
\hline $\begin{array}{l}\text { Substitute character or } \\
\text { substitute part of one or } \\
\text { more word(s) }\end{array}$ & I through letter or & $\begin{array}{l}\text { new character / or } \\
\text { new characters / }\end{array}$ \\
\hline Change to italics & — under matter to be changed & $\leftarrow$ \\
\hline Change to capitals & $\equiv$ under matter to be changed & $\equiv$ \\
\hline Change to small capitals & $=$ under matter to be changed & $=$ \\
\hline Change to bold type & $\sim$ under matter to be changed & $\sim$ \\
\hline Change to bold italic & $\bar{\sim}$ under matter to be changed & $\tilde{\omega}$ \\
\hline Change to lower case & Encircle matter to be changed & $\Rightarrow$ \\
\hline Change italic to upright type & (As above) & \\
\hline Change bold to non-bold type & (As above) & \\
\hline Insert 'superior' character & $\begin{array}{l}/ \text { through character or } \\
K \text { where required }\end{array}$ & $\begin{array}{l}y^{\prime} \text { or } y \\
\text { under character } \\
\text { e.g. } y^{2} \text { or } y^{2}\end{array}$ \\
\hline Insert 'inferior' character & (As above) & $\begin{array}{l}\lambda \\
\text { over character } \\
\text { e.g. } \hat{\Sigma}\end{array}$ \\
\hline Insert full stop & (As above) & $\odot$ \\
\hline Insert comma & (As above) & , \\
\hline Insert single quotation marks & (As above) & $\begin{array}{l}\dot{y} \text { or } \dot{x} \text { and/or } \\
\dot{y} \text { or } \dot{y}\end{array}$ \\
\hline Insert double quotation marks & (As above) & $\begin{array}{l}\ddot{y} \text { or } \ddot{x} \text { and/or } \\
\ddot{y} \text { or } \ddot{x}\end{array}$ \\
\hline Insert hyphen & (As above) & 1 \\
\hline Start new paragraph & 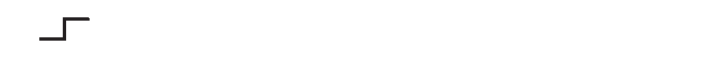 & 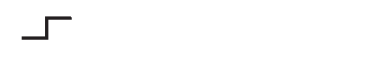 \\
\hline No new paragraph & $\infty$ & $\omega$ \\
\hline Transpose & $\sqcup$ & $\sqcup$ \\
\hline Close up & linking $\bigcirc$ characters & \\
\hline $\begin{array}{l}\text { Insert or substitute space } \\
\text { between characters or words }\end{array}$ & $\begin{array}{l}\text { I through character or } \\
K \text { where required }\end{array}$ & \\
\hline $\begin{array}{l}\text { Reduce space between } \\
\text { characters or words }\end{array}$ & $\begin{array}{l}\text { between characters or } \\
\text { words affected }\end{array}$ & $\uparrow$ \\
\hline
\end{tabular}

